\title{
Right Against Exploitation under Article 24 of the Indian Constitution
}

\author{
Nishant Pande*
}

\section{Abstract}

Article 24 of the Constitution prohibits the employment of children in hazardous environments. The provision is worded in a manner that allows horizontal application of the right guaranteed thereby. However, the Hon'ble Supreme Court of India's method of applying this horizontal right is obscure. On one hand, the Court in People's Union for Democratic Rights $v$. Union of India indulged in a direct horizontal application of the right conferred under the Article, while on the other hand, the Court in the case of M. C. Mehta v. State of Tamil Nadu, undertook a combined indirect horizontal and vertical application of the Article. This paper attempts to identify the exact manner of applicability of the right under Article 24, by tracing its development, with specific reference to the Supreme Court's interpretation of the same. Further, this paper explores the possibility of reading the right against exploitation in a more inclusive manner, as has been done for right to life under Article 21. The author has been inspired by the International community's perception of child labour, specifically, the Constitution of Ireland and the Bill of Rights of South Africa, in putting forward arguments to augment the expansion of the scope of Article 24.

Keywords: Article 21, Child labour, Comparative Constitutional Law, Purposive Interpretation, Right against Exploitation

\section{Introduction}

In order to delve into the application of fundamental rights, the most basic enquiry is to distinguish them as either 'vertical' or

* NALSAR University of Law, Hyderabad, India; nishant@nalsar.ac.in. 
'horizontal' in nature. ${ }^{1}$ While the vertical application of rights only compels the State to comply with them, horizontal application extends this requirement of compliance to private actors. ${ }^{2}$ The language of certain fundamental rights guaranteed under the Constitution, allows for horizontal application of those rights. For instance, the Hon'ble Supreme Court of India has, considering the language of Article 21, allowed the horizontal application of the 'right to life' on various occasions. ${ }^{3}$ Another provision of the Indian Constitution, which is worded similarly, is Article 24. This Article aims to prohibit child labour in factories and other hazardous jobs. ${ }^{4}$ However, unlike Article 21, which has been conferred direct horizontal application by the Supreme Court, 5 the Court's interpretation of Article 24 does not follow a uniform manner of application. This ambiguity is made amply clear when the holding in the People's Union for Democratic Rights v. Union of India ${ }^{6}$ (hereinafter referred to as the 'PUDR case') is viewed alongside the holding in M. C. Mehta v. State of Tamil Nadu (hereinafter referred to as the 'M. C. Mehta case') ${ }^{7}$. In the former, the Supreme Court construed Article 24 in a directly horizontal fashion, and in the latter, the Supreme Court interpreted the Article using a combination of indirect horizontal and vertical.

This paper attempts to determine the exact scope of the application of Article 24. To achieve the said goal, this paper will trace the development of the jurisprudence of Article 24, with specific reference to the Supreme Court's interpretation of the same. Further, this paper also explores the possibility of reading the right against exploitation under Article 24 in a broader manner as has been done for the right to life guaranteed under Article 21. To assist

1 OXFORD UNIVERSITY PRESS, THE OXFORD HANDBOOK OF THE INDIAN CONSTITUTION 640 (Sujit Choudhry et al. eds. 2nd ed. 2016).

2 Id.

${ }^{3}$ Indian Medical Association v. Union of India, (2011) 7 SCC 179; Consumer Education \& Research v. Union of India, AIR 1995(1) SC 637.

${ }^{4}$ INDIA CONST. Art 24.

5 Indian Medical Association, 7 SCC 179; Consumer Education \& Research, AIR 1995(1) SC 637.

6 People's Union for Democratic Rights v. Union of India, 1983 SCR (1) 456.

7 M. C. Mehta v. State of Tamil Nadu, (1996) 6 SCC 756. 
this analysis, the paper takes inspiration from the international community's perception of child labour, the Constitution of Ireland and the Bill of Rights of South Africa, the former having special indirect horizontal rights for children and the latter having laid great emphasis on the rights of the child.

\section{The Supreme Court and its Interpretation of Article 24}

Although the guarantee enshrined under Article 24 was included in the original text of the Indian Constitution under Article 18 of the Draft Constitution, 1948,8 cases concerning its interpretation have seldom come before the Supreme Court. The first time it did, was in the PUDR case. ${ }^{9}$ Though the case was primarily concerned with employment conditions of workers, it dealt with child labour as well. The Court observed that the constitutional prohibition under Article 24 must operate proprio vigore and it binds everyone by reason of its compulsive mandate. Justice Bhagwati identified two duties under Article 24 - the employers' duty to not employ children below the age of fourteen in hazardous work; and the state's duty to ensure that the employers don't breach their aforementioned duty. It is apparent that the Court intended to allow a direct horizontal application of Article 24.

Shortly after, the case of Labourers Working on Salal Hydro Project $v$. State of Jammu \& Kashmir ${ }^{10}$ came before the Court for adjudication. This was the first instance wherein the Court conflated the rationale for prohibiting child labour in hazardous environment, with the importance of education. The Court conceded to the fact that a child dropping out of school in order to assist his/her family to make ends meet, was an economic problem. The employment of children was only prohibited in hazardous environments because the socio-economic condition of India did not allow the complete

8 Draft Constitution of India, 1948, Constituent Assembly Debates India, https://www.constitutionofindia.net/historical_constitutions/draft_co nstitution_of_india_1948_21st\%20February\%201948.

9 Indian Medical Association, 7 SCC 179; Consumer Education \& Research, AIR 1995(1) SC 637.

10 Labourers Working on Salal Hydro Project v. State of Jammu \& Kashmir, AIR 1984 SC 177. 
prohibition of child labour. The Court recognized that it was the Central Government's duty to ensure the enforcement of Article 24. The Court suggested that the Central Government take responsibility for persuading workmen to send their children to school. Further, it was also held that the State was obligated to pay the school fees of such children and provide free books and other facilities like transportation etc. Essentially, the Court engaged in a vertical application of Article 24.

In the case of Sheela Barse v. Secretary, Children's Aid Society ${ }^{11}$, the Court enquired whether the respondent could be classified as a 'State' under Article 12 and whether such classification would determine whether the rights conferred under Articles 21 and 24 could be enforced against the respondent. Previously, in the PUDR case $^{12}$, the Court had identified that Articles 17, 23 and 24 were applicable against everyone. Thus, it was superfluous to determine if the respondent fell under the definition of 'State'.

Subsequently, in the M. C. Mehta case ${ }^{13}$, without reference to the Salal Hydro Project case ${ }^{14}$, the Court conflated the purpose of Article 24 , with the education of children. In this case, the Court was faced with the issue of child labour in the matchbox industry. According to the Court, child labour in hazardous places interfered with the education of children and was harmful to their mental and physical development. In its analysis, the Court read Articles 2415, 39(e)16 and $39(f)^{17}$ together to find that the legislative intent behind the enactment of the Child Labour (Prohibition and Regulation) Act, 1986 needs to be fulfilled. Interestingly, Articles 39(e) ${ }^{18}$ and 39(f) ${ }^{19}$ expect the State to make policies for securing the health of workers and to provide children opportunities, to develop in a healthy

\footnotetext{
11 Sheela Barse v. Secretary, Children's Aid Society, AIR 1987 SC 656.

12 People's Union for Democratic Republic v. Union of India, 1983 SCR (1) 456.

${ }_{13}$ M. C. Mehta v. State of Tamil Nadu, (1996) 6 SCC 756.

14 Salal Hydro Project, AIR 1984 SC 177.

15 INDIA CONST. art. 24.

16 INDIA CONST. art. 39(e).

17 INDIA CONST. art. 39(f).

18 INDIA CONST. art. 39(e).

19 INDIA CONST. art. 39(f).
} 
manner. The Court essentially conferred the State with a responsibility to ensure that the value under Article 24 is protected. This was clearly a vertical understanding of the text of Article 24. However, the Court did not stop here. Taking guidance from Articles 24, 39(e) and 39(f), it dictated that employers contravening the Child Labour (Prohibition and Regulation) Act, 1986 (hereinafter referred to as 'the 1986 Act') were liable to pay compensation for every child employed by them. The appointment of 'inspectors' is provided for in the 1986 Act $^{20}$, to make certain that the payment of the said compensation is deposited in the Child Labour Rehabilitation-cum-welfare fund. Thus, by using the legal structure of the State to secure a fundamental right, the Court also engaged in indirect horizontal application of Article 24.

The very next year, a Public Interest Litigation (PIL) was filed before the Supreme Court in order to prohibit the employment of children in the carpet industry. In this case, reported as Bandhua Mukti Morcha v. Union of India ${ }^{21}$, the petitioner contested that employment of children by carpet weavers of Uttar Pradesh was hazardous and thus, contrary to Article 24. The court stressed on the importance of children in the country's social progress, economic development, and peace and order. It also took cognizance of the State's responsibilities enumerated under Articles 39(e), 39(f) and 45. It found a connection between poverty and child labour and as child labour deprives children of a meaningful right to live, leisure, food, and education, their right to life protected under Article 21 was infringed.

This was followed by the case of State of Gujarat $v$. Hon'ble High Court of Gujarat 22 wherein the Court was faced with the question of minimum wages for prisoners. Although the case primarily dealt with the constitutionality of Article 23, the Court was of the opinion that inter alia Articles 17, 23 and $24^{23}$ were enforceable against all individuals, which necessarily bestowed a direct horizontal application to Article 24. A similar finding was

${ }^{20}$ Section 17, Child Labour (Prohibition and Regulation) Act, 1986, No. 61, Acts of Parliament, 1986.

${ }^{21}$ Bandhua Mukti Morcha v. Union of India, (1997) 10 SCC 549.

${ }^{22}$ State of Gujarat v. Hon'ble High Court of Gujarat, AIR 1998 SC 3164.

${ }^{23}$ INDIA CONST. 
documented in the Pradeep Kumar Biswas v. Indian Institute of Chemical Biology24, (hereinafter referred to as the P. K. Biswas case) wherein the court found that in case of violations of Articles 17, 23 or $24^{25}$ by a private individual, the aggrieved party could directly approach the court under Article 32. ${ }^{26}$

More than a decade after the case of State of Gujarat v. Hon'ble High Court of Gujarat, the Court was again faced with the question of interpreting Article 24 in the case of Childline India Foundation $v$. Allan John Waters. ${ }^{27}$ Though this case was a criminal matter, the Court read Articles 39(e), 39(f) and $45^{28}$ as being supplementary to Article 24. This brings forth the court's intent to protect the fundamental right in a vertical fashion and to read it alongside dignity, personality and education of children.

In Society of Unaided Private Schools of Rajasthan v. Union of India, (hereinafter referred to as the Unaided Society case) ${ }^{29}$ the Court acknowledged that primary responsibility to protect child rights, lies with the State and it must:

respect, protect and fulfil children's rights and has also got a duty to regulate the private institutions that care for children... Non-state actors exercising the state functions like establishing and running private educational institutions are also expected to respect and protect the rights of the child, but they are not expected to surrender their rights constitutionally guaranteed. ${ }^{30}$

Private individuals were expected not to infringe upon the guarantee, but this expectation was subject to their own fundamental rights. Thus, as per the Court, there was a clear hierarchy of duties imposed upon the State and others.

24 Pradeep Kumar Biswas v. Indian Institute of Chemical Biology, (2002) 5 SCC 111.

25 INDIA CONST.

26 INDIA CONST. art. 32.

27 Childline India Foundation v. Allan John Waters, (2011) 6 SCC 261.

28 INDIA CONST.

${ }^{29}$ Unaided Private Schools of Rajasthan v. Union of India, (2012) 6 SCC 1. ${ }^{30} \mathrm{Id}$. 
While dealing with the case of Subramaniam Swamy $v$. Union of India, ${ }^{31}$ the Court noted a party's argument regarding the fact that Articles 17, 23 and 2432 can be considered as recognition of horizontal rights under the Constitution. Similarly, in the case of India Young Lawyers Association v. The State of Kerala (hereinafter referred to as the Young Lawyers case) ${ }^{33}$, the Court held that Articles 23, 24 and 25(1) enumerate rights that can be applied horizontally, to preserve the dignity of individuals.

Furthermore, in its Daily Order dated January 4, 2018, in the matter of National Commission of Child Rights v. Rajesh Kumar, ${ }^{34}$ the Court, while citing the M. C. Mehta ${ }^{35}$ case, noted that child rights were sacred and that it is children who shall form the future of the country. The Court opined that the State has a great role insofar as protection of child's rights is concerned. Thus, the Court's interpretation seems to be to make the State primarily liable for guaranteeing that Article 24 is not violated.

From the analysis provided, it can be concluded that the Supreme Court has, time and again, found merit in the argument of applying Article 24 in a direct horizontal fashion. However, insofar as the primary duty of protecting the rights under the Article is concerned, the Court has bestowed the same upon the State. Private individuals have either not been expected to uphold the constitutional mandate or have been subject to lesser duty than the State.

The seven-judge constitutional bench in the P.K. Biswas ${ }^{36}$ case did find that in case of a violation of Article 24, the victim can approach the Court directly, i.e., it suggested direct horizontal application. The five-judge constitutional bench in the Young Lawyers case ${ }^{37}$ also

31 Subramaniam Swamy v. Union of India, AIR 2016 SC 2728.

32 INDIA CONST.

${ }^{33}$ India Young Lawyers Association v. The State of Kerala, MANU/SC/1094/2018.

${ }^{34}$ National Commission of Child Rights v. Rajesh Kumar, SLP 34251/17.

${ }^{35}$ M. C. Mehta v. State of Tamil Nadu, (1996) 6 SCC 756.

36 Pradeep Kumar Biswas v. Indian Institute of Chemical Biology, (2002) 5 SCC 111.

37 India Young Lawyers Association v. The State of Kerala, MANU/SC/1094/2018. 
had a similar finding to that of the P. K. Biswas ${ }^{38}$ case. That being said, substantial guidance regarding the nature of Article 24 and the rights and duties that flow out of it, can only be found in the three-judge bench decision of M. C. Mehta ${ }^{39}$ case. This results in the coexistence of two potentially irreconcilable legal positions - while the binding force of the constitutional benches dictate that Article $24^{40}$ must be understood as a horizontal right, the three-judge bench has deployed a vertical understanding of Article $24^{41}$ and has, thus, devised comprehensive structures to ensure that the State protects the right under the Article.

This conundrum can plausibly be resolved by the three-judge bench's dictum in the Unaided Society ${ }^{42}$ case. The court, in that case, found that: a) even when the primary responsibility to protect the right under Article $24{ }^{43}$ lay with the State, private actors performing state functions too, subject to their own constitutional rights, were expected to respect the right 44 and that b) legislation formulated in order to protect the rights under Article 2445, cast an obligation on non-state actors to protect and respect child rights. ${ }^{46}$ A cumulative reading of these two suggests that the court visualized a sui generis direct horizontal application of Article 24 against private actors performing state functions and indirect horizontal application of Article 24 against private actors in general.

\section{The International Community's Perspective on Child Rights}

In order to get a holistic picture of the international community's understanding of child rights and child labour, it is imperative to identify how the International Labour Organization (hereinafter

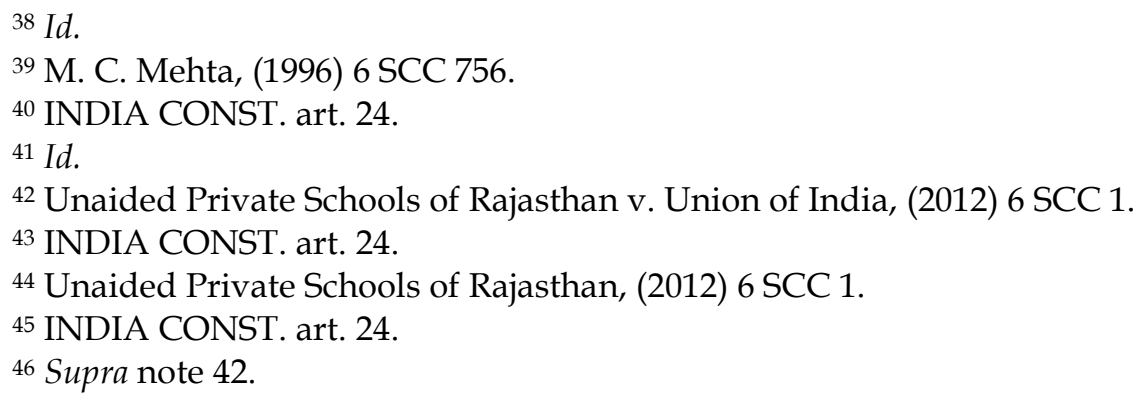


referred to as the I.L.O.) and The United Nations Convention on the Rights of the Child (hereinafter referred to as the C.R.C.) perceive the same. India is a member of the former and a signatory to the latter, and is obligated to respect international law. ${ }^{47}$

As far as the I.L.O. is concerned, several of its recommendations deal with the issue of child labour. Convention No. $138^{48}$ and Recommendation No. $146^{49}$, when read together, state that children should not be allowed to work at a young age (which should not be less than 18 years) and that national policies must provide for poverty alleviation and jobs for adults to ensure that their children do not become a part of the labour force. ${ }^{50}$ Recommendation No. $146^{51}$ also entails free and compulsory education for children, vocational training, extension of social security, appropriate facilities for the protection of children, etc. Furthermore, Convention No. 182 and Recommendation No. 190 cumulatively stress on expanding the definition of 'hazardous work' to include work that exposes children to physical, psychological and sexual abuse as well.52 Exposure to hazardous substances, processes, noises and vibrations, long work hours, night shifts and unreasonable confinement in the premises of the employer too, would form a part of the term 'hazardous work'.53 This expanded definition could, in the Indian context, bring work as domestic help, agricultural labourers, small-scale constructions workers and the like, under the definition of hazardous work for children.

\footnotetext{
47 INDIA CONST. art. 51.

48 Minimum Age Convention, C138, International Labour Organization (Jun. 26 1973), https:// www.ilo.org/dyn/normlex/en/ $f ? p=$ NORML EXPUB:12100:0::NO:12100:P12100_INSTRUMENT_ID:312283:NO.

${ }^{49}$ Minimum Age Recommendation, R146, International Labour Organization (Jun. 26 1973), https:// www.ilo.org/dyn/ normlex/ en/f?p =NORMLEXPUB:12100:0:: NO:12100:P12100_INSTRUMENT_ ID:312484:NO.

50ILO Conventions and Recommendations on child labour, INTERNATIONAL LABOUR ORGANIZATION, https://www.ilo.org/ipec/facts/ ILO conventionsonchildlabour /lang--en/index.htm.

51 Supra note 47.

${ }^{52} I d$.

${ }^{53} I d$.
} 
The C.R.C. on the other hand, imposes multiple duties on the signatory States. The States are expected to act in the best interest of a child without compromising equality and freedom of the child. ${ }^{54}$ States are further expected to respect the right to life of children. ${ }^{55}$ The Convention also imposes the duty on the States to guarantee education, health, social security, etc. for the children.56The mechanism of implementing the obligations under the C.R.C. is supposed to be coordinated in both a vertical and a horizontal fashion. ${ }^{57}$ The C.R.C. calls on non-state actors to comply with the provisions, however, it is the State that has a primary role to respect, protect and fulfil the rights of children. ${ }^{58}$ Incidentally, the burden of implementing the obligations under the C.R.C. is similar to how the Supreme Court of India has implemented Article $24^{59}$ in the Unaided Society ${ }^{60}$ case, i.e. holding the State to be the primary guardian of the rights of children, while non-State actors have a similar duty which is of a lower magnitude.

\subsection{The Constitution of Ireland}

The jurisprudence surrounding the Irish Constitution can be referred to ameliorate the rationale to expand the scope of Article 24 of the Indian Constitution. The Irish Supreme Court, prior to the insertion of Article 42A61, which specifically dealt with child rights $^{62}$, had identified various rights of the child under Article 40.3 of the Constitution 63 in the case of FN v. Minister for Education. ${ }^{64}$ It

54 Convention on the Rights of the Child, Nov. 20, 1989, 1577 U.N.T.S. 3.

$55 \mathrm{Id}$. at 6.

56 Id. at 9.

${ }^{57}$ Module 1: Overview of Child Rights in Development Cooperation, UNICEF, https://www.childrenrights.de/documents/upload/Child-RightsToolkit_Module1_Child-Rights-in-Development-Cooperation.pdf. 58 Id.

59 INDIA CONST. art. 24.

60 Unaided Private Schools of Rajasthan v. Union of India, (2012) 6 SCC 1.

61 Constitution of Ireland 1937 art. 42A.

62 UCD Constitutional Studies Group, A Guide to the referendum on the 31st Amendment to the Constitution, UCD SCHOOL OF LAW, https://www.ucd.ie/t4cms/Guide_to_the_31st_amendment.pdf.

${ }^{63}$ Constitution of Ireland 1937 art. 40.3.

64 FN v. Minister for Education [1995] 1 IR 409. 
interpreted the text of the Article in a broad manner, thus extending the State's duty to "defend and vindicate the personal rights of the citizen" to the protection of various rights of the child. ${ }^{65}$ The Article was in place to essentially protect the personal rights of citizens. However, the Irish Supreme Court, in the matter of $G v$ An Bord Uchtálab6, expanded the scope of the Article to include the unenumerated rights of children to be fed, to be reared, to be educated, to have an opportunity to live a life of dignity as a human being, etc. Subsequently, in $N$ v. The H.S.E., 67 these rights were made subservient to the rights of the family under Article 41 and the rights were subsumed within the family structure, other than exceptional scenarios. ${ }^{68}$ Notwithstanding the supremacy of the family in dealing with the concerns of the child, the Court had clearly gone beyond the mere text of the Constitution, to ensure the well-being of children and in the process, it expanded the scope of Article 40.3.69

Furthermore, as far as understanding of child rights is concerned, the requirement of protecting children's rights was considered so important, that under Article 42.5 (now repealed vide the $31^{\text {st }}$ Amendment), the State could have been compelled to supplant the role of the parents and vindicate the child's rights, in case the parents fail in their duties. ${ }^{70}$ Thus, there was also a possibility for the child to bring a claim against the State, in case it fails to intervene, albeit, the standard of proof required to succeed in such a claim would be extremely high. ${ }^{71}$ As per the case of North-Western Health Board v. H.W. ${ }^{72}$, the State's intervention was possible in instances like an immediate threat to the life or health of the child or an immediate threat to function as a human being, on account of dereliction of parental duties or neglect on part of the parents that

${ }^{65} \mathrm{FN}$ v. Minister for Education [1995] 1 IR 409.

${ }^{66}$ G v An Bord Uchtála [1980] 1 IR 32.

${ }^{67} \mathrm{~N}$ v. The H.S.E. [2006] 4 IR 375.

${ }^{68} \mathrm{~N}$ v. The H.S.E. [2006] 4 IR 375.

69 Supra note 62.

70 FN [1995] 1 IR 409.

71 Aoife Nolan, Holding non-state actors to account for constitutional economic and social rights violations: Experiences and lessons from South Africa and Ireland, 12 ICON 61, 73 (2014).

72North-Western Health Board v. H.W. [2001] 3 IR 635. 
causes an abandonment of the child etc. While the Indian Supreme Court has found the State to hold duties towards children under Article 24, which are essentially supplementary duties, ${ }^{73}$ for instance, providing transport to children, paying their school fee and for their books, the Irish Supreme Court's dictum all in all, makes the State duty-bound to stand-in for the parents and perform essential duties related to life and health of the child. Not only that, after the $31^{\text {st }}$ Amendment to the Irish Constitution ${ }^{74}$, Article 42A provides for a Constitutional provision similar to Article $21 \mathrm{~A}$ of the Indian Constitution. ${ }^{75}$ Article $42 \mathrm{~A}$ seeks to ensure that the religious, moral, intellectual, physical and social education of children is guaranteed and the children are further entitled to a certain minimum education - moral, intellectual and social. It is apparent that the Irish Constitution attaches great importance to the education, mental and physical well-being of the children of the country.

The sheer contrast between the positions of law in India and Ireland is thought provoking. On one hand, while Article 40.3 of the Irish Constitution only provided for protection of personal rights of citizens, the Irish Courts expanded its understanding to cater to not only the basic needs of children, but also to ensure that they lead a dignified life. On the other hand, the Indian Courts have interpreted Article 24 in a fashion that curtails its purpose to being a means to an end of education. This missed opportunity to expand child rights is further aggravated considering that Articles 39(e) ${ }^{76}, 39(\mathrm{f})^{77}$ and erstwhile Article $45^{78}$ of the Directive Principles of State Policy of the Indian Constitution, in actuality, provided for protection of child rights and dignity. Indian courts can definitely borrow from the Irish example to expand and emphasize child rights, especially under Article 24.

${ }^{73}$ Labourers Working on Salal Hydro Project v. State of Jammu E Kashmir, AIR 1984 SC 177.

74 Thirty-first Amendment of the Constitution (Children) Act 2012, (Act No. C31/2012).

75 INDIA CONST. art. 21A.

76 INDIA CONST. art. 39(e).

77 INDIA CONST. art. 39(f).

78 INDIA CONST. art. 45. 


\subsection{The Bill of Rights of South Africa}

To develop a perspective on the importance of child rights, a reference to the law of South Africa can be made, as Section 28 of Bill of Rights of South Africa, provides for special rights to children. ${ }^{79} \mathrm{~A}$ child is defined as a person who is under the age of 18 years and in matters concerning his or her right, the child's best interest must take paramount importance. ${ }^{80}$ These special rights conferred upon children include the right to have a name, nationality and birth, to be cared for in a familial environment, basic nourishment, health, social services and shelter, etc. ${ }^{81}$ Not only do the children have special rights like basic nutrition, shelter, health care and social services, etc., as per the Constitutional Court of South Africa's decision of Sonderup v Tondelli82, they also benefit from all the other rights provided in the Bill of Rights such as personal privacy, freedom of expression, freedom and security etc. The Constitutional Court, in $S v M^{83}$, has comprehended Section $28^{84}$ to be derived from the C.R.C., which has been interpreted to be the standard against which legislative measures and policies are to be measured. The wide formulation of Section $28(2)^{85}$ is, as per the Jooste $v$ Botha ${ }^{86}$ case, "...so all-embracing that the interest of the child would override all other legitimate interests of parents, siblings and third parties".

The Children's Act $2010^{87}$ was enacted to reinforce and endorse the rights provided under Section 28.88 The Criminal Law (Sexual Offences and Related Matters) Amendment Act, 2007 complements

\footnotetext{
${ }^{79}$ Nolan, Supra note 67 at 85.

${ }^{80} \mathrm{Id}$. at 86 .

$81 \mathrm{Id}$.

82 Sonderup v Tondelli 20011 SA 1171 (CC).

83 S v M 20083 SA 232 (CC).
}

84 Chapter 2 - Bill of Rights, Department of Justice and Constitutional Development, Republic of South Africa, https:// www.justice.gov.za/ legislation/constitution/SAConstitution-web-eng-02.pdf.

$85 \mathrm{Id}$.

86 Jooste v Botha 20002 SA 199 (T).

87 Children's Act 38 of 2010 (S. Afr.).

88 R. Songca, Evaluating of Children's Rights in South African Law: The Dawn of an Emerging Approach to Children's Rights, 44 COMP. \& INT'L L.J.S. AFR. 340, 344 (2011). 
the Children's Act, 2010 to protect children from sexual offences. Further, the Child Justice Act, 2008 creates a whole different justice system for matters involving children, who are in conflict with the law. ${ }^{89}$ The object of the Child Justice Act, 2008 is to provide restorative justice to children, so that they can be reintroduced into the society.

The plethora of South African legislations in place to protect the rights of children, is somewhat comparable to the stress the legislature of India has laid towards protection of children. The intention of the Indian legislature becomes evident on viewing various enactments like the Juvenile Justice Act, 200090, the Right to Education Act, 200991, the Protection of Children from Sexual Offences (POCSO) Act, $2012^{92}$ etc. Even the Indian judiciary has identified the value of children and their best interest. ${ }^{93}$

Insofar as child rights are concerned, India can learn from the South African experience. One important aspect is defining a child as an individual less than 18 years of age. This, in the context of free and compulsory education under Article $21 \mathrm{~A}^{94}$, extends the benefits of free education to a greater number of individuals. Furthermore, providing a familial environment for a child could also help in ensuring all-round development that is not merely guaranteed by providing food, clothing, shelter or education.

\section{The Right to Life vis-à-vis the Right against Exploitation}

The framers of the Indian Constitution provided for the right against exploitation under Articles 23 and $24 .{ }^{95}$ Article 24 has been phrased in a manner very similar to Article 21, with the former

${ }^{89} \mathrm{Id}$.

90 Juvenile Justice Act, 2000, No. 56, Acts of Parliament, 2000.

${ }^{91}$ Right to Education Act, 2009, No. 35, Acts of Parliament, 2009.

92 Protection of Children from Sexual Offences (POCSO) Act, 2012, No. 32, Acts of Parliament, 2012.

93 Labourers Working on Salal Hydro Project v. State of Jammu \& Kashmir, AIR 1984 SC 177; Childline India Foundation v. Allan John Waters, (2011) 6 SCC 261.

94 INDIA CONST. art. 21A.

95 India Const. Part III. 
beginning with the word "no child below... "96 and the latter with "no person shall..." 97 . However, in light of the Supreme Court's understanding of both these Articles, the similarities end here. Not only has Article $21^{98}$ been conferred direct horizontal application ${ }^{99}$, but also its title 'Protection of life and personal liberty' has been interpreted in a much broader fashion than Article $24^{100}$. The right to life under Article $21^{101}$ has been held to inter alia include substantive rights, such as the right to go abroad, the right to education, right to health and medical aid, the right to shelter, the right against delayed execution, right to livelihood, the right to privacy, the right against custodial death, the right against solitary confinement, assistance from doctors, the right against public hanging and the right against being handcuffed.102 Even the nonjusticiable Directive Principles of State Policy such as right of every child to a full development ${ }^{103}$, protection of under-trial prisoners ${ }^{104}$, protection of one's cultural heritage ${ }^{105}$, and the right to pollution free water and air ${ }^{106}$ have been read into the ambit of Article 21.

The rationale adopted to expand the scope of Article 21 has been of inherent importance with regards to the right of an individual to live a meaningful and dignified life. ${ }^{107}$ Thus, the Courts have over the years included more and more substantive rights under Article

96 INDIA CONST. art. 24.

${ }^{97}$ INDIA CONST. art. 21.

$98 \mathrm{Id}$.

99 Indian Medical Association v. Union of India, (2011) 7 SCC 179;

Consumer Education \& Research v. Union Of India, AIR 1995(1) SC 637.

100 INDIA CONST. art. 24.

101 INDIA CONST. art. 21.

102 Unni Krishnan v. State of A.P., 1993 SCR (1) 594.

103 Vinod Soni v. Union Of India, 2005 CriLJ 3408.

104 Moti Lal Saraf v. Union of India, 2007 (1) SCC Cri 180.

105 Vinod Soni, 2005 CriLJ 3408.

106 Subhash Kumar v. State of Bihar, AIR 1991 SC 420.

107 Olga Tellis v. Bombay Municipal Corporation, 1985 (3) S.C.C. 545; Charles Sobraj v. Supdt. Central Jail, Tihar, A.I.R. 1978 S.C. 1514; Bandhua Mukti Morcha v. Union of India, (1984) 3 S.C.C. 161; Bombay v. D.R. Nadkarni, (1983) 1 S.C.C. 124; Vikrant Deo Singh Tomar v. State of Bihar, (1988) Suppl. S.C.C 734; R. Autyanuprasi v. Union of India, (1989) 1 Suppl. S.C.C. 251. 
21, as they considered them necessary for an individual to lead a dignified life. From the doctrinal research undertaken in this paper, it is apparent that the right against exploitation of children ${ }^{108}$ has not been conferred a wide interpretation. A contrario constitutional courts have, on multiple occasions, perceived Article 24109 as an instrument to guarantee the right to education of children. ${ }^{110}$ Why two similarly worded fundamental rights have been interpreted by the judiciary in such different ways, remains to be seen. The grave contrast between Articles $21^{111}$ and $24^{112}$ lies in the fact that the former is, by way of interpretation, a bearer of substantive rights and the latter is, again by way of interpretation, merely a way of supporting a substantive right under Article $21 \mathrm{~A}^{113}$ i.e., the right to education.

\subsection{Expanding the Scope of Article 24}

The Right against Exploitation (Articles 23 and 24) ${ }^{114}$ under the Indian Constitution has two different aspects. Sub-clause (1) of Article 23115 states that: "Traffic in human beings and begar and other similar forms of forced labour are prohibited and any contravention of this provision shall be an offence punishable in accordance with law."

As far as the interpretation of this Article is concerned, in the PUDR case ${ }^{116}$, the Supreme Court found that it was applicable in a

108 INDIA CONST. art. 24.

$109 \mathrm{Id}$.

110 M. C. Mehta v. State of Tamil Nadu, (1996) 6 SCC 756; India Young Lawyers Association v. The State of Kerala, MANU/SC/1094/2018; A. Srirama Babu v. The Chief Secretary to the Government of Karnataka, Bangalore, 1998 (1) KarLJ 191; Dr. Mithileshwar Kumar v. The State of Bihar, 2000 (1) SCT 402 (Patna); Tamil Nadu Higher Secondary Post Graduate Teachers' Association v. The State of Tamil Nadu, (2008) 1 MLJ 256.

111 INDIA CONST. art. 21.

112 INDIA CONST. art. 24.

113 INDIA CONST. art. 21A.

114 INDIA CONST.

115 INDIA CONST. art. 23.

116 People's Union For Democratic Republic v. Union Of India, 1983 SCR (1) 456 . 
direct horizontal fashion. It was also found that the scope of Article 23117 is unlimited and any form of forced labour, paid or unpaid, was prohibited under it. ${ }^{118}$ The rationale for this prohibition was that any kind of forced labour would offend human dignity and no servitude can be allowed to exist in a country that upholds human rights. ${ }^{119}$ It is evident that the Court undertook a wider view of the right enumerated under Article 23120, to ensure that the spirit of the right against exploitation is upheld. The Court did not resort to limiting the types of labour that would fall under the prohibition; instead it acknowledged that any action that deprives a person of choice could be regarded as forced. ${ }^{121}$ Thus, the Supreme Court has previously indulged in expanding the scope of a right against exploitation, enumerated under Article 23.

If the scope of interpretation of Article 24 is to be broadened, the various contours of the right must be determined. To begin with, it is imperative to determine what 'exploitation' exactly is. The Black's Law Dictionary defines 'exploitation' as - "The act of taking advantage of something, especially the act of taking unjust advantage of another for one's own benefit"122. Evidently, the extent of the definition of exploitation would not be limited to mere hazardous employment in factories, mines, etc. Borrowing the logic for expanded interpretation from Courts' understanding of Article $21^{123}$ and the precedent relating to expanding Article 23124, the right against exploitation of children also has a potential of expansion to include the myriad forms of workplace exploitation children are subjected to as domestic helps, agricultural labourers, etc.

The Supreme Court in the case of Maneka Gandhi v. Union of India125 has held that "when interpreting the provisions of the Constitution conferring fundamental rights, the attempt of the court should be

117 INDIA CONST. art. 23.

118 People's Union for Democratic Republic, 1983 SCR (1) 456.

119 Id.

120 INDIA CONST. art. 23.

${ }^{121}$ Id; State of Gujarat v. Hon'ble High Court of Gujarat, AIR 1998 SC 3164.

${ }^{122}$ Exploitation, BLACK'S LAW DiCTIONARY 600 (9th ed. 2009).

123 INDIA CONST. art. 21.

124 INDIA CONST. art. 23.

125 Maneka Gandhi v. Union of India, 1978 AIR 597. 
to expand the reach and ambit of the fundamental rights rather than to attenuate their meaning and content". Without an expansion of Article 24, the idea of children living a life free from exploitation would be a distant reality and thus, the right against exploitation of children would be rendered incomplete. In fact, as the current law stands, by reading the right against exploitation of children as a means to the end of ensuring education for children, this negative right becomes obsolete.

Insofar as the importance of children is concerned, it has already been noted that, while tracing the jurisprudence surrounding Article 24, the Supreme Court has emphasized on the primal role children play in the country's social progress, economic development, peace and order, etc. ${ }^{126}$ The legislature, too, has taken cognizance of the same and has introduced Article 21 $\mathrm{A}^{127}$, amended Article $45^{128}$ and the Right to Education Act, 2009129 to cater to the educational needs of children in the country. That being said, the wording of the right under Article $24{ }^{130}$, is specific and it deals only with 'hazardous employment' per se. This specific wording disallows expanding Article $24^{131}$ to the extent of the expansion conferred upon Article 21. ${ }^{132}$

By way of purposive interpretation of Article 24133, however, the author identifies a possibility to expand the scope of the Article in a fashion that is in conformity with the basic idea behind the provision, i.e., to prevent the exploitation of children at workplaces. Thus, in keeping with the jurisprudence conferring immense importance to the rights of a child, it is only reasonable to expand the scope of the rights the children were conferred by the Drafters of the Constitution, to include myriad forms of workplace exploitations. The references to the C.R.C., recommendations of the I.L.O., the Irish Constitution, and the South African Bill of Rights

\footnotetext{
126 Bandhua Mukti Morcha v. Union of India, (1997) 10 SCC 549.

127 INDIA CONST. art. 21A.

128 INDIA CONST. art. 45.

129 Supra note 87.

130 INDIA CONST. art. 24.

${ }^{131} \mathrm{Id}$.

132 INDIA CONST. art. 21.

133 INDIA CONST. art. 24.
} 
also substantiate the argument in favour of expanding the definition of Article 24. While the I.L.O. also suggests the expansion of the definition of 'hazardous work' to include work that exposes children to physical, psychological and/or sexual abuse ${ }^{134}$, the C.R.C. enumerates a plethora of rights, which children possess, and the corresponding duties to protect them lie primarily with the State. The Irish Constitution serves as an example of expanding the scope of a right ensuring protection of personal rights ${ }^{135}$, to include child rights and both the Irish Constitution ${ }^{136}$ and the South African Bill of Rights ${ }^{137}$ display clearly how important the rights of children have been viewed by other jurisdictions. The courts in India have played an instrumental role in expanding the scope of one's fundamental rights to ensure that the intentions of the drafters of the Constitution are appropriately reflected. Thus, taking into account the basic premise behind Article 24, that is, to prevent the workplace exploitation of children, there is no reason to not allow the children of this country to be free from the vices of any kind of workplace exploitation, which robs them of their dignity as human beings. This also translates into the fact that Article 24138 cannot be a mere means to the end of guaranteeing education and must be allowed a wide, independent existence in order to tackle myriad forms of workplace exploitations of children.

\section{Conclusion}

This paper analyses in depth the fundamental right guaranteed under Article 24. It starts off with tracing the Supreme Court of India's interpretation of the Article and concludes that, save certain exceptions, the Court has preferred vertically applying the right against exploitation under Article 24. The corresponding duty to respect the negative right has either not been expressly expanded to include private individuals, or simply confers a lesser degree of

\footnotetext{
134 Supra note 48.

135 Constitution of Ireland 1937 art. 40.3.

136 Constitution of Ireland 1937 art. 42A.

${ }^{137}$ Chapter 2 - Bill of Rights, Department of Justice and Constitutional

Development, Republic of South Africa, https:// www.justice.gov.za/ legislation/constitution/SAConstitution-web-eng-02.pdf.

138 INDIA CONST. art. 24.
} 
responsibility on private parties. Moreover, the Court has also conflated education and Article 24 in a manner that the latter is an instrument in guaranteeing the former. ${ }^{139}$ The author also identifies that the case of Society of Unaided Private Schools of Rajasthan $v$. Union of India ${ }^{140}$ provides for the current position of law pertaining to Article 24, i.e., a primary responsibility upon the State to protect the right and non-State actors expected to respect the right.

In order to argue in favour of expanding the scope of Article 24, the author relies on the I.L.O. and the C.R.C., to conclude that the international community greatly emphasizes on the requirement of protecting rights of children. Additionally, as per the recommendations of the I.L.O., there is a possibility of expanding the definition of 'hazardous work'. The Constitution of Ireland can be a guiding example, wherein special rights for children have been identified by the Irish Supreme Court under Article 40.3, which prima facie only guarantees the protection of civil rights.

A comparison is drawn between Articles $21^{141}$ and $24^{142}$ wherein it is concluded that while the Supreme Court has expanded the ambit of the right to life to circumscribe more and more rights over the years, to ensure a more meaningful and dignified existence of a person, Article 24143 has been reduced to a mere instrument to guarantee the substantive right of education to children. The jurisprudence surrounding Article 23144 makes it amply clear that the Supreme Court has expanded the definition of 'forced' to include any kind of labour that deprives one of his/her right to freedom of occupation. The specific wording of Article 24 makes it impossible to interpret it broadly as it deals only with 'hazardous employment'. However, purposive interpretation can be resorted to in order to expand the scope of Article 24 to include other forms of exploitations a child might face at his or her employment. This wider interpretation would free Article $24^{145}$ from the shackles of

${ }^{139}$ M. C. Mehta v. State of Tamil Nadu, (1996) 6 SCC 756.

140 Unaided Private Schools of Rajasthan v. Union of India, (2012) 6 SCC 1.

141 INDIA CONST. art. 21.

142 INDIA CONST. art. 24.

${ }^{143} \mathrm{Id}$.

144 INDIA CONST. art. 23.

145 INDIA CONST. art. 24. 
being a mere instrument to ensure education of children and will grant it a scope that would better represent the basic premise behind including it in the Indian Constitution. 